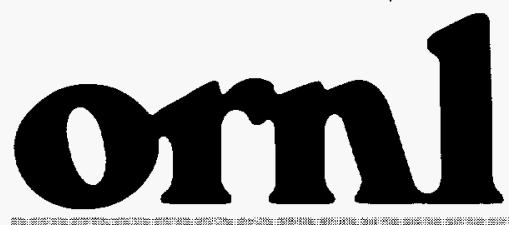

OAK RIDGE NATIONAL LABORATORY
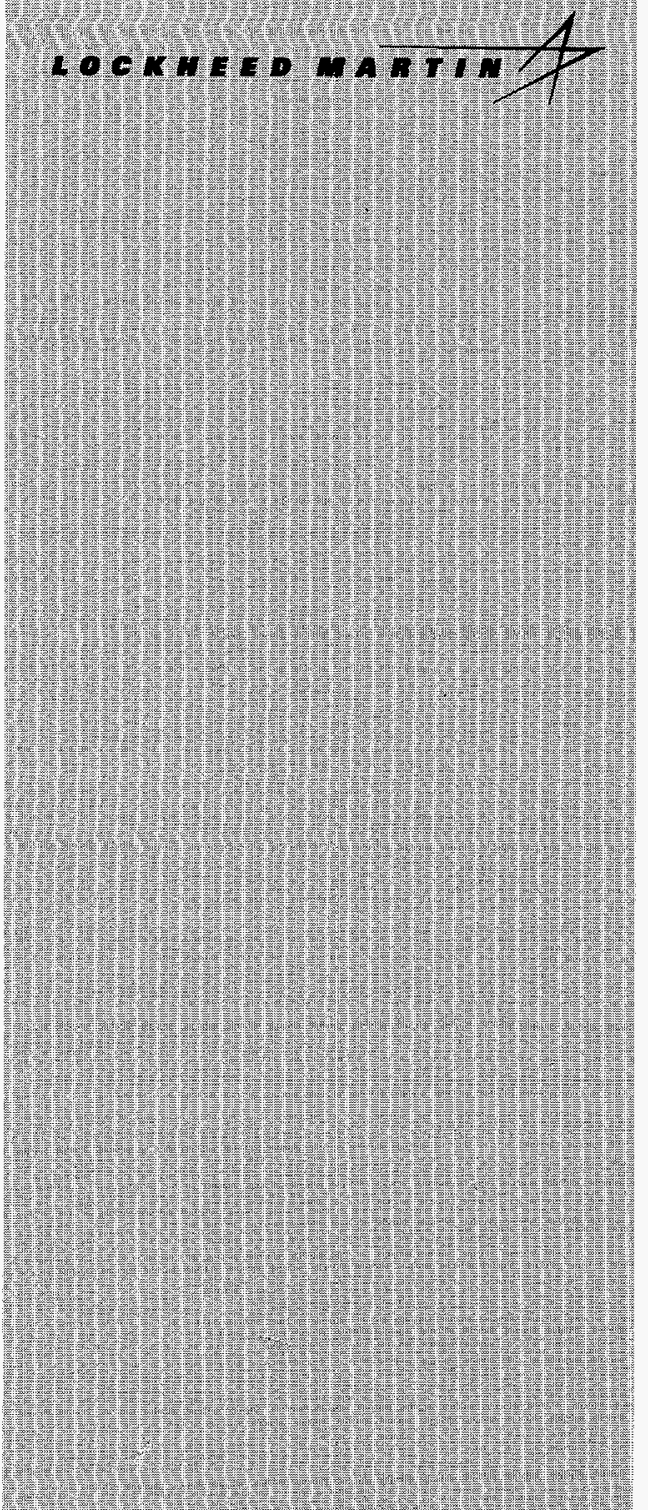

WWMAED AND OPERATEO BY

LOCKHEED WARII ENERGY RESEARCH COSPORATIOS FOA THE UITEO STATES

DEPARTIENT OF EIERGY

\section{Technical Support Section Annual Work Plan for FY 1997}
B. P. Adkisson
K. L. Allison
R. P. Effler
R. A. Hess
T. A. Keeble
S. M. Odom
D. R. Smelcer

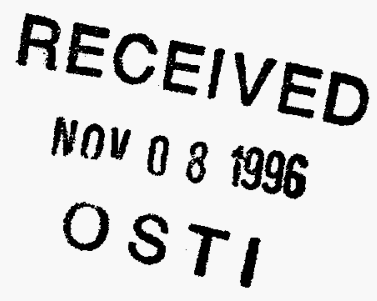

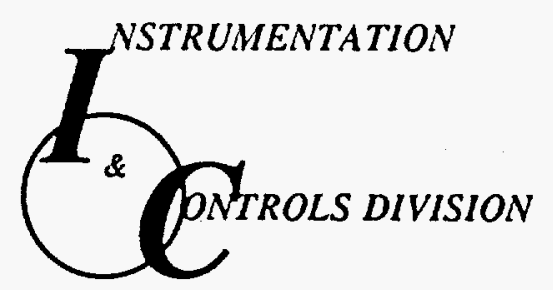


This report has been reproduced directly from the best available copy.

Available to DOE and DOE contractors from the Office of Scientific and Technical Information, P.O.Box 62, Oak Ridge, TN 37831; prices available from (423) 576-8401, FTS 626-8401.

Available to the public from the National Technical Information Service, U.S. Department of Commerce, 5285 Port Royal Rd., Springfield, VA 22161

This report was prepared a an account of work sponsored by an agency of the United States Government. Neither the United States Government nor any agency thereof, nor any of their employees, makes any warranty, express or implied, or assumes any legal liability or responsibility for the accuracy, completeness, or usefulness of any information, apparatus, product, or process disclosed, or represents that its use would not infringe privately owned rights. Reference herein to any specific commercial product, process, or service by trade name, trademark, manufacturer, or otherwise, does not necessarily constitute or imply its endorsement, recommendation, or favoring by the United States Government or any agency thereof. The view and opinions of authors expressed herein do not necessarily state or reflect those of the UnitedStatesGovernment or any agency thereof. 
Instrumentation and Controls Division

\title{
TECHNICAL SUPPORT SECTION ANNUAL WORK PLAN FOR FY 1997
}

B. P. Adkisson

K. L. Allison

R. P. Effler

R. A. Hess

T. A. Keeble

S. M. Odom

D. R. Smelcer

Date Published: October 1996

\author{
Prepared by \\ OAK RIDGE NATIONAL LABORATORY \\ Oak Ridge, Tennessee 37821-6285 \\ managed by \\ LOCKHEED MARTIN ENERGY RESEARCH CORP. \\ for the \\ U.S. DEPARTMENT OF ENERGY \\ under contract DE-AC05-96OR22464
}




\section{DISCLAIMER}

Portions of this document may be illegible in electronic image products. Images are produced from the best available original document. 
1. INTRODUCTION/OVERVIEW $\ldots \ldots \ldots \ldots \ldots \ldots \ldots \ldots \ldots \ldots \ldots \ldots \ldots \ldots \ldots$

2. ANALYSIS OF PREVIOUS YEAR'S PERFORMANCE $\ldots \ldots \ldots \ldots \ldots \ldots \ldots \ldots \ldots 2$

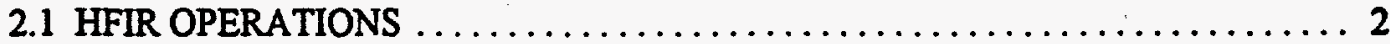

2.2 MAINTENANCE ENGINEERING SUPPORT $\ldots \ldots \ldots \ldots \ldots \ldots \ldots \ldots \ldots \ldots$

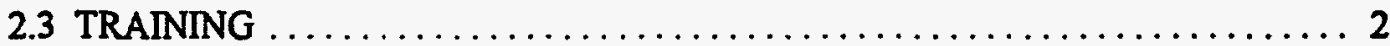

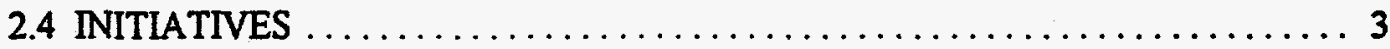

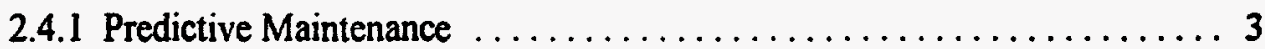

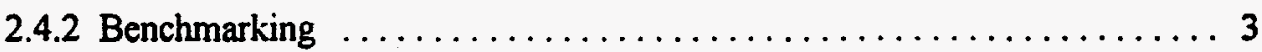

2.4 .3 Research Support ............................. 3

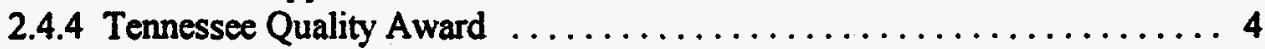

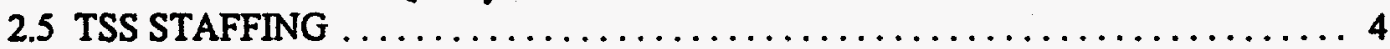

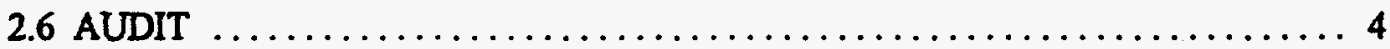

2.6.1 Management and Administration Proficiencies .............. 4

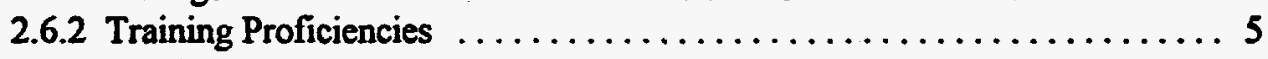

2.6 .3 Quality Assurance Proficiency ................... 5

2.6.4 Radiation Protection Proficiency .................... 5

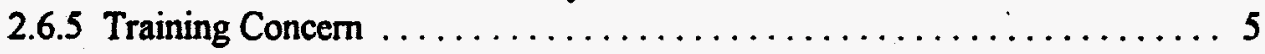

2.6.6 Environmental Protection and Waste Management Concern ........ 5

2.7 FUNDING .................................... 6

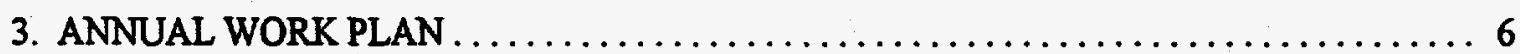

4. FINANCIAL ANNUAL WORK PLAN $\ldots \ldots \ldots \ldots \ldots \ldots \ldots \ldots \ldots \ldots \ldots \ldots$

5. LONG-RANGE WORK PLAN $\ldots \ldots \ldots \ldots \ldots \ldots \ldots \ldots \ldots \ldots \ldots \ldots \ldots \ldots \ldots, \ldots$ 


\section{INTRODUCTION/OVERVIEW}

The Technical Support Section (TSS) of the Instrumentation and Controls (I\&C) Division of Oak Ridge National Laboratory (ORNL) provides technical services such as fabrication, modification, installation, calibration, operation, repair, and preventive maintenance of instruments and other related equipment. Work performed by TSS is in support of basic and applied research and development (R\&D), engineering, and instrument and computer systems managed by ORNL.

It is the mission of TSS to support programs and policies of ORNL, emphasizing safety and ensuring cost-effective support for R\&D.

Because the activities and priorities of TSS must be adapted to the technical support needs of ORNL, the TSS Annual Work Plan is derived from, and driven directly by, current trends in the budgets and activities of each ORNL division for which TSS provides support. Trends that will affect TSS planning during this period are reductions in the staffing levels of some $R \& D$ programs because of attrition or budget cuts.

TSS does not have an annual budget to cover operating expenses incurred in providing instrument maintenance support to ORNL. Each year, TSS contacts ORNL division finance managers or division finance officers to obtain information concerning projected funding levels of programs and facilities they manage. TSS workforce and resource projections are based on the information obtained and are weighted depending on the percentage of support provided to that division or program. Annually, TSS sets the standard hourly charge rate for the following fiscal year. The standard rate is based on the projected annual inflation rate, proposed increases or decreases in manpower due to perceived changes in program or division funding, upgrade of aging equipment or facilities, overhead burden, compliance with new requirements or directives, labor contract negotiations, and the fringe benefit rate. The standard rate is charged to customer accounts or work orders as the work is performed. A cost variance occurs when there is a difference between the actual cost per hour and the standard rate per hour. Typically, this variance is positive during months of high fringe benefit cost (holidays and vacation) or when materials or equipment are costed by Accounts Payable. Variances are negative during months with minimal fringe benefit cost and when materials purchased for maintenance support are charged back to customer accounts.

The Long-Range Work Plan (see Sect. \#5) is based on estimates of impact of the long-range priorities and directions of the Laboratory. Identifiable proposed new facilities and programs provide additional basis for long-range planning. After identifying long-range initiatives, TSS planning includes future training requirements, reevaluation of qualifications for new hires, and identification of essential test equipment needed in new work.

Although TSS has no direct responsibility for the maintenance or repair of real property, it does perform breakdown maintenance, preventive maintenance, and calibration of Laboratory production and experimental equipment, all of which is used for programmatic purposes. Operating expense funds from supported divisions support this type of equipment. 


\section{ANALYSIS OF PREVIOUS YEAR'S PERFORMANCE}

\subsection{HFIR OPERATIONS}

Although full-time maintenance support to the High Flux Isotope Reactor (HFIR) operational systems was assumed by Research Reactors Division (RRD) on October 1, 1994, the TSS Management Information System (MIS) continues to generate calibration and preventive maintenance (PM) recalls, archive maintenance history, and technician training records. On request, TSS personnel also provide training and technical support and install and maintain non-operational HFIR instrumentation and controls systems such as those in Materials Irradiation and other experimental facilities.

\subsection{MAINTENANCE ENGINEERING SUPPORT}

TSS Maintenance Engineer/Planners contributed substantially to several projects for ORNL research divisions and Laboratory support. Among these were the following:

* X-ray Personnel Safety Feature Specification and Design.

- Experimental Solid State Division Ellipsometer Circuitry.

- Oak Ridge Research and Bulk Shielding Reactor Pool Water Gamma Monitors.

* Safety Interlocks for Experimental Laser Facility.

* Advanced Driver Advisory System.

\subsection{TRAINING}

As a result of an evaluation of the TSS training program by the Department of Energy (DOE) against the criteria of DOE Order 5480.20A and an internal environmental, safety, health, and quality (ESH\&Q) review, the TSS training program underwent a major renovation last year. A consolidated training program for the I\&C Division was developed to provide a consistent approach to baseline training. The program is designed to develop a standard training plan; to identify mandatory training, required training, and developmental opportunities; and to report individual training status. Division Procedure QA-IC-OP40 replaced existing training policy and procedures to simplify documentation and comply with training responsibilities identified in the I\&C Division ES\&H Plan for FY 1996.

Each employee completed a training-needs assessment, which consisted of an "Environmental Safety and Health Checklist." Instrument technicians completed the "Technician Baseline Evaluation Checklist," and TSS managers/supervisors completed the "Technical Support Section Management/Supervision Checklist." Personnel who must be qualified to support non reactor nuclear facilities were identified as working in two major areas: process instrumentation and radiation-monitoring instrumentation. The DOE Fundamentals Handbook, Instrumentation and Control, Vols. 1 and 2, were used as references for fundamental knowledge-based study guides. Examinations provided evidence of entry-level competency for initial qualification. On-The-Job Training (OJT) Checklist/Evaluation Guides provided evidence of skills-based initial qualification. 
Personnel not requiring qualification to perform work assignments were also included in the training process and were categorized as non nuclear facility employees. Information collected from various needs assessments was entered into a database that will track the initial training/qualification, last time requalified, and next due date for requalification.

Training needs were updated to reflect the changing scientific and technological environment at ORNL. In FY 1996, 1904 training events were completed by 143 TSS personnel, an average of 13.3 events per person. The I\&C TSS MIS creates status reports that reflect real-time training data, providing supervisors with an accurate assessment of their personnel's qualifications to meet current customer needs and all safety requirements.

\subsection{INITIATIVES}

\subsubsection{Predictive Maintenance}

A team of technical personnel from I\&C TSS and R\&D sections, Research Reactors Division, Engineering Technology Division, and Plant and Equipment Division identified several ORNL physical systems that would lend themselves to $R \& D$ of advanced predictive maintenance (PdM) techniques. A seed money proposal for pursuit of this activity is underway.

\subsubsection{Benchmarking}

The TSS led a group representing the maintenance organizations from Lockheed Martin (LM) to benchmark Tennessee Valley Authority's (TVA's) outsourced personal computer (PC) operation. Discussions included the experiences, advantages, and disadvantages encountered with $-65 \%$ of their 10,000 PC systems using this competitively bid agreement. Being a government agency, TVA has several similarities to LM. TVA's representative felt that maintenance of PCs could be better performed with higher user satisfaction by in-house personnel.

It was noted that the value-added services provided by in-house personnel are often not recognized. It was also mentioned that the motivation of in-house repair technicians is generally higher because they share many of the same goals and missions as the user. The TSS has used this information to evaluate its services.

\subsubsection{Research Support}

It was brought to the attention of the TSS support team for the Environmental Sciences Division that a forest productivity research program was being hindered because no means existed of precisely controlling the temperature in open-topped carbon dioxide chambers. The TSS team took the initiative and successfully conceived and reduced to practice a system to enable this to be done. Using evaporative coolers to replace the blower boxes on standard open-topped chambers and a feedback control system based on two data loggers and a multi tasking computer, the team perfected a novel but exceedingly efficient means of maintaining the temperature in these boxes from ambient to ambient $+4^{\circ} \mathrm{C}$. This accomplishment was indispensable in experiments to determine the interactive effects of $\mathrm{CO}_{2}$ and other climate variables on tree species. These experiments are part of a core project of the International Geosphere-Biosphere Program. 


\subsubsection{Tennessee Quality Award}

The Tennessee Quality Award is a three-step process. TSS received Level 1 in October 1994. This past year TSS applied for and was selected to receive the Level 2 award. Level 2 is the Quality Commitment level. This level is the intermediate level of organizations that have progressed to the point of demonstrating serious commitment to the use of total quality principles. Level 2 of the process was to perform an internal assessment formatted using the following seven Baldrige criteria:

1. Leadership

2. Information and Analysis

3. Strategic Planning

4. Human Resource and Development

5. Process Management

6. Business Results

7. Customer Focus and Satisfaction

\subsection{TSS STAFFING}

Because of promotions and retirements, TSS lost four staff members during this reporting period. Five instrument technicians were added during the first and second quarters of FY 1996. These technicians were on the K-25 impact list and were transferred into TSS to help compensate for the loss of 18 staff members during the last major company retirement incentive program. Four permanent secretaries were also added this past year, reducing our temporary staff to one.

Current staffing levels are expected to remain relatively constant during FY 1997 as we continue to streamline our operations and reduce operating costs.

\subsection{AUDIT}

During the period between April 29 and May 3, 1996, the I\&C Division and the TSS underwent an audit to verify the implementation and effectiveness of the management systems for environment, safety, health and quality. The audit satisfied the review requirement of DOE Order 5482.1B and provided independent verification of the Price-Anderson Amendment Act requirements compliance.

This audit was comprised of an overview briefing, document reviews, staff interviews, facility walkthrough, and field observations. Overall, the division had three findings, 14 concerns, and 12 proficiencies. The TSS audit results included zero findings, two concerns, and eight proficiencies.

\subsubsection{Management and Administration Proficiencies}

The back-to-work meetings in the TSS appear to be effective in both communicating "lessons learned" and soliciting and discussing task-related ESH\&Q issues.

The TSS is to be applauded for progressing to Level 2 of the Tennessee Quality Award. 
The Photo-Metal Lab in Building 3587 has the capability to fabricate written operating procedures from photo-metal, which can be attached to facility walls or desk tops. This would be useful in operating areas and control rooms where contamination is a concern, since the photo-metal procedures would be durable and easily decontaminated and would not evoke environmental concerns associated with disposal.

\subsubsection{Training Proficiencies}

At I\&C's request, an informal DOE-Oak Ridge Operations review of our training program under DOE Order 5480.20A was completed, and activities are underway to answer suggestions and comments.

TSS takes advantage of free training opportunities on the Internet to provide up-to-date answers to technicaquestions.

\subsubsection{Quality Assurance Proficiency}

The TSS Personal Computer Group has found an innovative way to address the challenge of Windows95. Microsoft's advertising has led customers to expect the installation of this new operating system to go smoothly, but there are often problems with incompatibility because of the great variety of PCs being serviced. Installation is also a time-consuming process. The situation threatened to undermine customers' trust in the Personal Computer Maintenance Groups. They responded by conducting periodic meetings. Now, as soon as experience is gained with troublesome chips, boards, and software, it can be shared with those likely to face the problem at ORNL, K-25, and $\mathrm{Y}-12$.

\subsubsection{Radiation Protection Proficiency}

A heavy gun safe with an electronic combination lock is used for source storage in Building 2033. The heavy gauge steel construction provides an added measure of shielding and security.

A source control custodian in Building 2033 maintains a list of qualified source users along with their respective radiation worker training expiration dates in the source signout log.

\subsubsection{Training Concern}

Training records were not protected in a one-hour fire-rated cabinet or in duplicate storage (as required by ORNL-SPP-X-AD-7). Subsequently, the training records have been moved to the required file cabinets.

\subsubsection{Environmental Protection and Waste Management Concern}

The degreaser used in Building 3587 has been changed from TMS Freon 113 to HCFC-141B, a Class II Ozone Depleting Substance (ODS). A review was made by the Air Group. It has been determined that the degreaser is not out of compliance at this time. However, before January 1 , 1997, all use of HCFC-141B in a degreaser tank must cease. The use of HCFC-141B will still be allowed for wipe-down cleaning. 


\subsection{FUNDING}

The total TSS budget for FY 1996 was $\$ 9,489,479$ and did not include any overhead funding. This represents an overall charge-out rate of $\$ 45.15$ per hour for the more than 209,000 hours of service provided by the TSS. Overall reduction from the FY 1995 rate amounts to $6.4 \%$ and calculates to a total savings of $\$ 647,630$ in charges to customers. This reduced rate was achieved by analyzing the components in the TSS budget and devising ways to reduce spending and increase productivity. The major components of the TSS rate include payroll and fringe (76.5\%), materials (3\%), and support services $(20.5 \%)$.

The FY 1997 rate has been adjusted for inflation and set at $\$ 46.70$ per hour. This amounts to an increase from the FY 1996 actual operating rate of 3.4\%. Additionally, the TSS continues to analyze the budget and promote more cost-efficient ways to conduct business.

\section{ANNUAL WORK PLAN}

Each major research division was contacted to determine the projected programmatic level of funding for the next fiscal year. Most divisions projected that their funding levels would remain near those of FY 19 or slightly decrease. Overall, FY 1997 operating-expense-funded maintenance and repair requirements for ORNL are projected to be relatively level with those of FY 1996. Analysis of DOE orders and technical training needs to evaluate training program costs, work force requirements, and types of qualifications for new hires was performed. Routine and breakdown maintenance is expected to remain relatively stable, enabling work to be performed by current staffing levels. 


\section{FINANCIAL ANNUAL WORK PLAN}

\section{Maintenance}

Administration

Calibration \& Testing

Communications/Security

Division Support

Electronic Instrumentation

Engineering Support

Fabrication \& Metal-Photo

Facility Support

Networking \& System Support

Personal Computers

Process \& Industrial Instrumentation

Special Electronics \& Environmental Monitoring

TOTAL (\$ x 100)

\section{$\begin{array}{llllllll}\text { FY } 1996 & \text { FTEs } & \text { FY } 1997 & \text { FTEs } & \text { FY } 1998 & \text { FTEs } & \text { FY } 1999 & \text { FTEs }\end{array}$}

Budget Assigned Budget Assigned Budget Assigned Budget Assigned

$\begin{array}{cccccccc}843 & 12 & 701 & 10 & 722 & 10 & 744 & 10 \\ & & 701 & 10 & 722 & 10 & 744 & 10 \\ 703 & 10 & 771 & 11 & 794 & 11 & 818 & 11 \\ & & 981 & 14 & 1,011 & 14 & 1,041 & 14 \\ 984 & 14 & 981 & 14 & 1,011 & 14 & 1,041 & 14 \\ & 17 & & & & & & \end{array}$

$\begin{array}{cccccccc} & & 631 & 9 & 650 & 9 & 669 & 9 \\ 1,335 & 19 & 1,332 & 19 & 1,372 & 19 & 1,413 & 19 \\ 1,195 & 17 & 771 & 11 & 794 & 11 & 818 & 11 \\ 1,406 & 20 & 1,332 & 19 & 1,372 & 19 & 1,413 & 19 \\ 914 & 13 & 1,192 & 17 & 1,227 & 17 & 1,264 & 17\end{array}$

$914 \quad 13$
7 


\section{LONG-RANGE WORK PLAN}

Long-range work projections by TSS are based on projections and funding levels of ORNL research divisions. 


\section{INTERNAL DISTRIBUTION}

1. B. P. Adkisson

2. G. T. Alley

3. K. L. Allison

4. M. E. Boren

5. C. R. Cinnamon

6. B. C. Davis

7. R.P. Effler

8. H. C. Ford

9. J. L. Hammontree

10-14. R. A. Hess

15. J. O. Hylton

16. G. D. Inman

17. J. M. Jansen

18. T. A. Keeble

19. D. N. Keller

20. W. L. Marsh
21. D. W. McDonald

22. L. D. Merryman

23. G. N. Miller

24. S. M. Odom

25. J. E. Payne

26. D. G. Prater

27. D. R. Smelcer

28. C. T. Stansberry

29. J. O. Stiegler

30. J.H. Swanks

31. C. W. Tompkins

32. J. D. White

33. Central Research Library

34. Laboratory Records - Record Copy

35. I\&C Division Publications Office 
ORNL/TM-13330

\section{EXTERNAL DISTRIBUTION}

36. Edward Cumesty, Assistant Manager for Laboratories, DOE-ORO, P.O. Box 2001, Oak Ridge, TN 37831-8600

37. Ronald O. Hultgren, ORNL Site Manager, DOE-ORO, ORNL Building 4500N, Room 211, MS 6269 (or P.O. Box 2008, Oak Ridge, TN 37831-6269)

38. Michele G. Branton, ORNL Maintenance Program Manager, DOE-ORO, ORNL Building 4500N, Room 231, MS 6269 (or P.O. Box 2008, Oak Ridge, TN 37831-6269)

39-42. D. C. Queen, DOE-ORO, Y-12 Plant, Building 9114, Oak Ridge, TN 37831-8722

43. Ron Moore, The RM Group, Inc., 12024 Broadwood Drive, Knoxville, TN 37922

44. David Norton, Houston Advanced Research Center, 4800 Research Forest Dr., The Woodlands, TX 77381

45. Robert M. Taylor, Leeds and Northup, Sunneytown Pike, North Wales, PA 19454

46. M. M. Sevik, Caderock Division, Naval Surface Warfare Center, Code 70, Bethesda, MD 20084-5000

47. Ernesto Suarez, Pratt \& Whitney, P.O. Box 109600, MS 617-87, W. Palm Beach, FL $33410-9600$

48-49. Office of Scientific and Technical Information, U.S. Department of Energy, P.O. Box 62, Oak Ridge, TN 37831 